\title{
COMPETENCE MANAGEMENT AND IMAGE OF POLICE OFFICERS IN POLAND
}

\author{
Dorota KUREK \\ War Studies University, Warsaw, Poland \\ d.kurek@akademia.mil.pl
}

\begin{abstract}
Competence management is an issue that has become an area of particular interest not only for organisations from the business community, but also for public institutions, including institutions whose primary objective is to ensure security and public order. The group of such institutions includes, among others, the Polish Police. The level of competence available to officers, which is manifested through the prism of their behaviour, is at the same time the basis for the assessment of officers' activities, which translates into their social image. The image of an organization and its employees influences the attitudes of the interested parties, including their approval manifested by support and understanding, or disapproval in the scope of the tasks performed. The quality of the image of police officers also affects the citizens' sense of security. Bearing the above in mind, in the first part of the article, the process of managing the competences of police officers is presented as an action aimed at equipping officers with competences necessary for effective performance of official duties and fulfilling a servile role in relation to the society. In the second part of the article, the results of empirical research devoted to the issue of the image of police officers are presented.
\end{abstract}

\section{Key words: competence management, image, Police officers}

\section{Introduction}

The competences that police officers have at their disposal, manifested in the course of their service performance, are the result of the competence management process which has been implemented in the Polish Police for a number of years. Due to the fact that competences are not directly visible, and their existence is concluded on the basis of observable behaviour, there is a need for a specific analysis of the indicated issues, as the behaviour of police officers is assessed by the society on a daily basis and translates into the image of police officers. Bearing the above in mind, the main objective of the conducted research was to provide additional information on the main research problem posed, formulated as the following question: whether, and if so, what is the relationship between the competences and the quality of the image of police officers in Poland?

\section{The essence of professional competences}

The term competence in literature on human resources management appeared in R. White's 1959 publication Motivation reconsidered. The concept of competence [1], however, gained popularity thanks to the article written by D.C. McClelland from 1973 entitled Testing for competence rather than for 'intelligence' [2]. Competences in the indicated publications were defined as a set of individual characteristics influencing the perception of oneself as well as the way 
of behaviour in the professional environment. McClelland, who was a proponent of a behavioural approach, stressed that based on an employee's behaviour it is possible to conclude what competences such an employee possesses, which have their origin both in the internal potential human being and in the environment in which such a person functions [3].

Looking for factors influencing human behaviour, L.M. Spencer and S. M. Spencer, on the basis of the results of their research, pointed to the existence of the socalled iceberg of competence. The authors, defining competences as motivation, personality traits, self-image, knowledge or behavioural skills [4], emphasised that the easily observable manifestation of competences are skills and knowledge (treated as competence components) considered as the tip of the iceberg. On the other hand, the elements that are "under water" are motivation, personality, norms and values, self-image and perception of social role. This approach to competence clearly shows which components of a competence are easy and difficult to change, which is of great importance in the process of employee selection as well as in the management of their competences in the professional environment.

Scientists, however, unanimously emphasise that competences relate to performance, are observable through the prism of behavioural assessment and refer directly to the organisation and its character [5].

\section{Competences and image}

The observability of competences plays a key role, especially in relation to professions that are socially important and have a social service character, and such a profession is undoubtedly that of a policeman. On the basis of behaviour displayed by police officers during their daily service, the society makes conclusions about the competences of officers and thus their ability to perform their professional duties. The assessment carried out as a result of both direct and indirect experiences translates into a social assessment of the image of officers and thus the level of public trust.

The image in the source literature is defined as an image consisting in the reflection in the consciousness of previously perceiving elements of reality [6], or as an image created in the mind of an interested party, being a construct of both cognitive and affective evaluation, based on the evaluation of experiences. The image of an organisation, including employees, is created not on the basis of objective facts, but on the basis of impressions of individuals [7] resulting, among others, from the frequency of exposure to a given stimulus (frequency of contact with the organisation), the individual's own needs, their level of satisfaction and presented attitudes [8].

An image is an ambiguous and ephemeral concept, oscillating between imagination and reason, expectations and reality [9]. From an ontological point of view, an image is an effect of interpretation of the attributes of a given object. The image is connoted by the sign, which means that its meaning beam generates different emotional impressions in different audiences [10]. The impressions translate into an emotional attitude towards the organisation, employees and are reflected in the attitudes of the audience, which may consider the organisation to be professional, but at the same time may not like it. Evaluation is always subjective, which results from individual cognitive processes, experiences of the individual and the environment in which it operates, and which determines values and norms of behaviour.

To sum up, the image contains both cognitive and emotional evaluation constructs, which translates into attitudes, including expectations. Therefore, when discussing the image, special attention should be paid to the audience who use the 
image, as it is the basis for a proper assessment of both the conditions for the creation of the image and its consequences.

\section{Management of competences of police officers}

Management of competences of police officers is a coordinated set of actions taken already at the stage of building the profile of competences of an ideal candidate for service. On the basis of the developed profile, the course of the process of selecting and then training and improving the competences of officers was designed, while the process of improvement is also based on the profiles of competences of police officers adequate to the requirements imposed on policemen of particular departments. As a result of actions taken in the area of competence management, officers are adjusted to the requirements at job positions, while the level of adjustment translates into social assessment of officers' actions and their image.

In order to unify the course of both the process of training and improvement of police officers in Poland, the Act of 6 April 1990 on the Police [11] was issued together with a number of executive acts in the form of ordinances, orders and decisions of the Chief Commander-in-Chief of the Police. The aforementioned legal acts made it possible to construct a competence management system, which is based not only on the activities of the Police Academy in Szczytno, the Police Training Centre in Legionowo, the Police School in Stupsk, the Police School in Katowice, the Police School in Piła or the Police Training Centre in Łódź with its registered office in Sieradz, as the process of improving officers is also carried out at the command level within the so-called local or external improvement, which enables the training to be tailored to the individual needs of individual units and departments of the police.

The system of development of competences of police officers is based on two basic subsystems: the vocational training subsystem and the professional development subsystem. The basic training system is dedicated to officers who are just starting their service in the Police, as well as to officers (graduates of higher education institutions) who are in permanent service and must obtain higher professional qualifications in order to perform service on specific positions. The second part of the competence development system includes a system of professional development, which may take the form of central, local and external development.

\subsection{Basic training in the Police}

Basic training shall be conducted in accordance with the curriculum introduced by Decision No. 405 of the Police Chief Commandant of 22 December 2016 on the basic vocational training programme [12] and shall comprise 1117 lesson hours, delivered during 143 training days. The aim of the training is to prepare an officer, both in theoretical and practical spheres, to perform official tasks at the basic level, in the position of a policeman in the preventive service in the organisational units of patrol and intervention units and police prevention units. The training is obligatory, which means that every future police officer must complete it, regardless of professional experience and education.

In the years 2009-2017, 86 editions of the basic vocational training were completed by 52,263 police officers. Vocational training is also conducted for university graduates and police officers in permanent service. The purpose of the training is to prepare police officers to perform official tasks at positions where higher professional qualifications are required. Completion of vocational training for university graduates entitles them to take the officer's exam, which was taken by 9,515 policemen over the course of 2009-2017 [13].

\subsection{Improvement of police officers}

The second element of the system for the development of competences of police officers is the vocational training 
subsystem, which plays a complementary role in relation to the basic vocational training system. The aim of police officers development is to supplement, update, deepen and acquire by already professionally experienced officers new skills necessary in everyday service within the framework of performing specialist tasks, typical for a given type of service.

Professional development of police officers may take the form of central training, local training and external training. Central training conducted by police schools and the Police Academy in Szczytno takes the form of specialist courses as well as other undertakings implemented both in the stationary system and with the use of electronic distance learning. In 20152017, 57,465 officers completed specialist courses [13].

Vocational training of police officers may also be conducted in the form of the socalled local training, which is aimed at maintenance and improvement of physical fitness and shooting skills of officers. It may also take the form of instruction necessary for the proper performance of official activities and tasks. The third form of professional training dedicated to police officers is the so-called external training. The basis for organising this type of training is the identified training needs, which cannot be met in the form of central and local improvement [14]. In 2017, 97 undertakings were organised just in the Police Training Centre in Legionowo, which constituted $42 \%$ of all such activities in the whole country [13].

The implementation of activities aimed at improving officers is necessary not only due to changes in the legal regulations and the equipment used, but above all, this need results from the growing social expectations regarding the manner of performing service, the behaviour of officers and their effectiveness.

\section{Competences and image - research results}

5.1. Description of the examinations and tests

In order to respond to the research problem, in January 2019 empirical research was carried out with the use of the diagnostic survey method and the survey technique. The research was of a pilot nature and was carried out on a sample of 100 people. The respondents were both women and men aged from 18 to 35 . Selection of the research sample on the basis of age was purposeful, as the opinions of potential candidates for service in the Police were analysed.

\subsection{Key competences of police officers - research results}

As part of the survey, respondents were asked to assess the competences of police officers in Poland. The research shows that almost $59 \%$ of the respondents assessed the competences held by police officers negatively. The opposite opinion was expressed by over $23 \%$ of the respondents. Over $18 \%$ of the respondents did not give an unambiguous answer to this question.

As part of the survey, the respondents were also asked to assess the work of the Police. A positive opinion was given by $46 \%$ of the respondents, $29 \%$ did not answer this question, and a negative opinion was given by $25 \%$ of the respondents. Referring to the results of research commissioned by the Police Headquarters within the framework of the Polish Crime Survey 2017, 68.7\% of respondents considered police actions to be effective [15], while according to the survey conducted by CBOS (Public Opinion Research Center) in 2017, 68\% of the respondents rated the activities of the Police as good [16]. The presented results clearly indicate the complexity of the image of police officers and its multi-aspects. Negative assessment of competences does not translate into the assessment of police effectiveness. 


\subsection{Image of police officers - research results}

The second aspect, which was analysed during the research, was the image of police officers, which is based on both direct and indirect experiences of the society, with a significant role of the media and local environment. The conducted research shows that $66 \%$ of the surveyed expressed a negative opinion on the image of police officers, while $17 \%$ of the surveyed expressed the opposite opinion. Negative evaluation of the image of officers is also visible in the answers to other questions in the survey, including the question concerning the appreciation by the public of the work of police officers. In the opinion of $65 \%$ of the respondents, the work of police officers is not properly appreciated (the relation between the assessment of the image and the appreciation of the work of police officers was discovered; $p=0.028, \mathrm{~V}$ Cramera 0.279), although trust in police officers is also declared by $65 \%$ of the respondents.

The image of police officers is of significant importance in the surveyed group, as the opinions of potential candidates for work in the police were analysed. A negative image resulting also from the assessment of officers' competencies is of significant importance in the process of making decisions on whether to apply for admission to service in the Police.

Therefore, one may be tempted to make a hypothesis about the impact of the negative image of police officers on the difficulty in selecting candidates for service, as manifested by the existence of 4.5 thousand vacancies in the Police (as of January 2019) [17].

\subsection{Identification of relations between research variables}

Taking into account the obtained results of research in the scope of evaluation of competences of police officers and their image, the existence of statistical dependencies between the indicated variables was analysed. To this end, the level of statistical significance and the strength of the relationship between the social assessment of police officers' competences and image were calculated. The research shows that the significance level $\mathrm{p}$ was lower than 0.05 and amounted to 0.001 , which revealed the existence of a statistically significant relationship at the average level between variables (V Cramera 0,329), which allowed for positive verification of the hypothesis assumed. Analysing the revealed dependencies, it was confirmed that a negative assessment of competence translates into a negative assessment of the image of police officers. The indicated dependence is important from the point of view of the competence management process of officers, which should be subject to detailed analysis in order to identify the reasons for the negative assessment of officers' competences. A negative assessment of society, which is subjective in nature, may be related to the existence of irregularities in the organisation and course of the process of managing the competences of police officers. The reasons for the negative assessment of officers' competences should also be seen in the manner in which officers are presented in the media, which also indicates the need to pay more attention to the social image of officers, which is a certain kind of national benefit, as it translates into the feeling of security of citizens.

\section{Conclusions}

The issue of competence management, as well as shaping the image of police officers is a multi-faceted issue, also a difficult one to analyse due to the subjectivity of competence assessment, as well as the transience of the image. As part of her research, the author tried to show both the essence of competence and the image of officers, including a brief outline of the process of police officers' competence management, in order to show the complexity of the whole process. 
The results of the research made it possible to confirm the existence of a correlation between the social assessment of competences and the image of police officers. Disclosure of such a relationship, which took place through statistical research, confirms how difficult it is to build the image of police officers, which depends on the quality of assessment of competences of officers resulting from the competence management process in the Polish Police.

\section{References}

[1] White R.W., Motivation reconsidered: The concept of competence, Psychological Review, 66(5), pp. 297-333, 1959.

[2] McClelland D.C., Testing for competence rather than for 'intelligence', The American Psychologist, 28(1), pp. 1-14. 1973.

[3] McClelland D.C., Identifying Behavioral Event Interviews, Psychological Science, 9(5), pp. 331-339, 1998.

[4] Spencer L.M., Spencer S.M., Competence at work, New York: John Wiley \& Sons, 1993, p. 4.

[5] Turek D., Wojtczuk-Turek A., Kompetencje transferowalne. Przeglad definicji, modeli $i$ stanowisk teoretycznych, [in:] ed. by S. Konarski, D. Turek, Kompetencje transferowalne. Diagnoza. Kształtowanie. Zarzadzanie, Oficyna Wydawnicza SGH, Warszawa 2010, p. 15.

[6] Przetacznikowa M., Makiełło-Jarża G., Podstawy psychologii ogólnej, WSiP, Warszawa 1982, p. 88.

[7] Hope E., Public relations instytucji użyteczności publicznej, Gdańsk 2005, p. 4.

[8] Waszkiewicz A., Wizerunek organizacji. Teoria praktyka badania wizerunku uczelni, Instytut Dziennikarstwa Uniwersytetu Warszawskiego, Warszawa 2011, p. 25.

[9] Boorstin D.J., The Image: A Guide to Pseudo-Events in America, New York 1961, p. 193.

[10] Hall S., Kodowanie i dekodowanie, Przekazy i Opinie, no. 1/2, 1987.

[11] Act of 6 April 1990 on the Police (Journal of Laws 2017, item 2067, as amended).

[12] Decision No 405 of 22 December 2016 of the Police Commander-in-Chief on the basic vocational training programme (Journal of Laws KGP (NPH), item 77, as amended).

[13] Reports on vocational training and in-service training organised and carried out by the police - 2009-2017 reports, Komenda Główna Policji (National Police Headquarters).

[14] Ordinance of the Minister of Internal Affairs and Administration of 19 June 2007 on detailed conditions for vocational training and further training in the Police (Journal of Laws No. 126, item 877, as amended).

[15] Polish Entrepreneurship Survey - 2017, KGP (.

[16] Research report no. 40/2018, Ocena działalności instytucji publicznych, CBOS, p. 9.

[17] https://www.prawo.pl/kadry/wakaty-w-policji-2019,355225.html. 